\title{
Arbuscular Mycorrhizal Fungal Communities in the Soils of Desert Habitats
}

\author{
Martti Vasar ${ }^{1}$, John Davison ${ }^{1}{ }^{\mathbb{D}}$, Siim-Kaarel Sepp ${ }^{1}$, Maarja Öpik ${ }^{1}$, Mari Moora ${ }^{1}{ }^{\mathbb{D}}$, Kadri Koorem ${ }^{1}{ }^{\mathbb{D}}$, \\ Yiming Meng ${ }^{1, * \mathbb{D}}$, Jane Oja ${ }^{1}$, Asem A. Akhmetzhanova ${ }^{2}$, Saleh Al-Quraishy ${ }^{3}$, Vladimir G. Onipchenko ${ }^{2}$, \\ Juan J. Cantero ${ }^{4,5}{ }^{-}$, Sydney I. Glassman ${ }^{6}{ }^{(D}$, Wael N. Hozzein ${ }^{3,7} \mathbb{D}^{-}$and Martin Zobel ${ }^{3,8}$
}

check for updates

Citation: Vasar, M.; Davison, J.; Sepp, S.-K.; Öpik, M.; Moora, M.; Koorem, K.; Meng, Y.; Oja, J.; Akhmetzhanova, A.A.;

Al-Quraishy, S.; et al. Arbuscular Mycorrhizal Fungal Communities in the Soils of Desert Habitats. Microorganisms 2021, 9, 229. https://doi.org/10.3390/ microorganisms 9020229

Academic Editor: Alberto

Miguel Stchigel

Received: 30 December 2020

Accepted: 19 January 2021

Published: 22 January 2021

Publisher's Note: MDPI stays neutral with regard to jurisdictional claims in published maps and institutional affiliations.

Copyright: (c) 2021 by the authors. Licensee MDPI, Basel, Switzerland. This article is an open access article distributed under the terms and conditions of the Creative Commons Attribution (CC BY) license (https:/ / creativecommons.org/licenses/by/ $4.0 /)$.
1 Institute of Ecology and Earth Sciences, University of Tartu, 51005 Tartu, Estonia; martti.vasar@ut.ee (M.V.); john.davison@ut.ee (J.D.); siimsepp@ut.ee (S.-K.S.); maarja.opik@ut.ee (M.Ö.); mari.moora@ut.ee (M.M.); kadri.koorem@ut.ee (K.K.); jane.oja@ut.ee (J.O.)

2 Department of Ecology and Plant Geography, Lomonosov Moscow State University, 119234 Moscow, Russia; assemok@mail.ru (A.A.A.); vonipchenko@mail.ru (V.G.O.)

3 Zoology Department, College of Science, King Saud University, Riyadh 11451, Saudi Arabia; squraishy@KSU.EDU.SA (S.A.-Q.); whozzein@ksu.edu.sa (W.N.H.); martin.zobel@ut.ee (M.Z.)

4 Instituto Multidisciplinario de Biología Vegetal, Universidad Nacional de Córdoba, CONICET, Córdoba 5000, Argentina; juanjocantero@gmail.com

5 Departamento de Biología Agrícola, Facultad de Agronomía y Veterinaria, Universidad Nacional de Río Cuarto, Río Cuarto 5804, Argentina

6 Department of Microbiology and Plant Pathology, University of California, Riverside, CA 92521, USA; sydney.glassman@ucr.edu

7 Botany and Microbiology Department, Faculty of Science, Beni-Suef University, Beni-Suef 62511, Egypt

8 Department of Botany, University of Tartu, Tartu 51006, Estonia

* Correspondence: yiming.meng@ut.ee

\begin{abstract}
Deserts cover a significant proportion of the Earth's surface and continue to expand as a consequence of climate change. Mutualistic arbuscular mycorrhizal (AM) fungi are functionally important plant root symbionts, and may be particularly important in drought stressed systems such as deserts. Here we provide a first molecular characterization of the AM fungi occurring in several desert ecosystems worldwide. We sequenced AM fungal DNA from soil samples collected from deserts in six different regions of the globe using the primer pair WANDA-AML2 with Illumina MiSeq. We recorded altogether 50 AM fungal phylotypes. Glomeraceae was the most common family, while Claroideoglomeraceae, Diversisporaceae and Acaulosporaceae were represented with lower frequency and abundance. The most diverse site, with 35 virtual taxa (VT), was in the Israeli Negev desert. Sites representing harsh conditions yielded relatively few reads and low richness estimates, for example, a Saudi Arabian desert site where only three Diversispora VT were recorded. The AM fungal taxa recorded in the desert soils are mostly geographically and ecologically widespread. However, in four sites out of six, communities comprised more desert-affiliated taxa (according to the MaarjAM database) than expected at random. AM fungal VT present in samples were phylogenetically clustered compared with the global taxon pool, suggesting that nonrandom assembly processes, notably habitat filtering, may have shaped desert fungal assemblages.
\end{abstract}

Keywords: assembly rules; dryland; fungal community; fungal diversity; mycorrhiza

\section{Introduction}

Drylands already cover about $41 \%$ of the Earth's surface [1], and climate changeprimarily by increasing aridity and temperature-and intensive land use exacerbate the risk of land degradation and desertification in the near future [2,3]. Indeed, drylands are predicted to cover half of terrestrial Earth's surface by 2100 even under a moderate emissions scenario [4].

Plant communities in desert areas are unique in many respects. Desert plants have biochemical, physiological and morphological adaptations allowing them to tolerate dry 
and warm conditions $[5,6]$. Some of these adaptations may be linked to mutualistic interactions. In particular, mycorrhizal fungi help plants tolerate stressful conditions [7]. Arbuscular mycorrhizal (AM) fungi (phylum Glomeromycota; [8]) are an ancient group of root symbionts that associate with more than $80 \%$ of plants in terrestrial ecosystems, gaining plant-assimilated carbon while supplying their hosts with nutrients (mainly phosphorus) and improving their tolerance to abiotic stress and pathogens [9]. AM fungi are found on all continents and many species-level phylogroups (phylogenetically defined groupings of taxa described by DNA sequences) exhibit wide distributions [10].

Arbuscular mycorrhizal fungi are generally thought to help desert plants tolerate stress [11,12], although aridity can reduce overall AM fungal abundance [13]. AM fungi can promote plant drought resistance by producing hyphae with access to small soil pores, greatly increasing the capacity for belowground water uptake [14]. However, AM fungal benefits to hosts may decline under extremely low water availability, as dry soil conditions can inhibit the flow of phosphorus from AM fungi to plants [15]. Indeed, in some extremely arid and nutrient poor areas, non-mycorrhizal plants are more abundant [16,17]. However, a meta-analysis showed that under experimental drought conditions, grasses colonized by AM fungi generally tend to grow larger than those without mycorrhizal symbionts [18]. There is also evidence that water-limited plants grown in arid soils allocate relatively more biomass to AM fungi [19].

While some studies have elucidated how AM fungi can themselves tolerate drought and in turn help their plant partners tolerate drought stress [20,21], the diversity, distribution and ecology of AM fungal communities occurring in arid conditions remains poorly understood. Experimental reduction of rainfall for nearly four months did not result in obvious changes to AM fungal community composition and diversity [22]. While it is true that small organisms tend to tolerate extremely dry conditions better than large ones [23], AM fungal spores are very large among fungi, being up to 1000 times larger than spores of the Ascomycota [24]. Thus, while it is likely that there are fewer constraints on AM fungi than on the plant communities occurring in arid conditions, they might still be more constrained than other microbial taxa such as bacteria and the vast majority of fungi, which have smaller spores. Indeed, spore-based studies have shown relatively low AM fungal diversity in desert regions, with several fungal taxa unique to deserts and other generally widespread taxa missing [25]. AM fungal diversity in Oman was found to be as low as two taxa in a sand dune habitat, but as high as fifteen taxa in more benign desert locations, such as date palm plantations [25], and as high as forty-four taxa in a desert in northwestern China [26]. A DNA-based analysis revealed from nine to eighteen AM fungal phylotypes in the roots of plants growing in a 30 by $30 \mathrm{~m}$ plot in a desert ecosystem in Australia [10], another DNA based analyses found ten AM fungal phylotypes in Vachellia pachyceras roots from a Kuwaiti desert [27].

Harsh growth conditions for either plants or fungi may both directly influence the composition of desert AM fungal communities and represent a barrier to fungal dispersal. Indeed, ectomycorrhizal fungi show strong biogeographic structure at continental scales [28,29], while dispersal limitation may be weaker for AM fungi at global [30] and regional scales [31]. Data on wind dispersal of AM fungi are mixed [32], while animals have been shown to act as dispersal vectors for AM fungi [33-35]. In sparsely vegetated deserts with low densities of both host plants and vector animals, dispersal may not be effective and thus, AM fungal occurrence in desert landscapes may be patchy.

The aim of this study was to gain a preliminary overview of the diversity and species composition of AM fungal communities in different desert ecosystems worldwide based on analysis of DNA extracted from soil. We wanted to sample the full pool of AM fungal taxa, and soil sampling is the straightforward way to do this. We compared soil AM fungal communities in six different desert sites spanning six countries and four continents. We hypothesized that the diversity of AM fungi in desert ecosystems is low and varies between deserts based on edaphic conditions. We also hypothesized that desert communities comprise distinctive taxa that are uncommon in other biomes. 


\section{Methods}

\subsection{Data Collection}

Soil for molecular identification of AM fungi was sampled in desert areas in northwestern Argentina, central Australia, southern Israel, southeastern Kazakhstan, central Saudi Arabia and the southwestern United States of America (Figure 1, Tables 1 and 2). Vegetation varied from very sparsely $(<5 \%)$ vegetated desert to woody shrubland with vegetation cover over $60 \%$. In each desert location, we identified the site that was least disturbed by human activities. In each sampling site, about $20 \mathrm{~g}$ of $(0-5 \mathrm{~cm})$ topsoil was collected from twenty randomly located points within approximately a 50 by $50 \mathrm{~m}$ sampling area. For further analysis the samples were pooled per site, resulting in an approximately $300 \mathrm{~g}$ soil sample for each site. The soil samples were dried within $24 \mathrm{~h}$ using silica gel at room temperature and then carefully homogenized. A $2 \mathrm{~g}$ subsample of soil was collected from the whole sample for further molecular analysis; the remainder was stored for geochemical analysis.

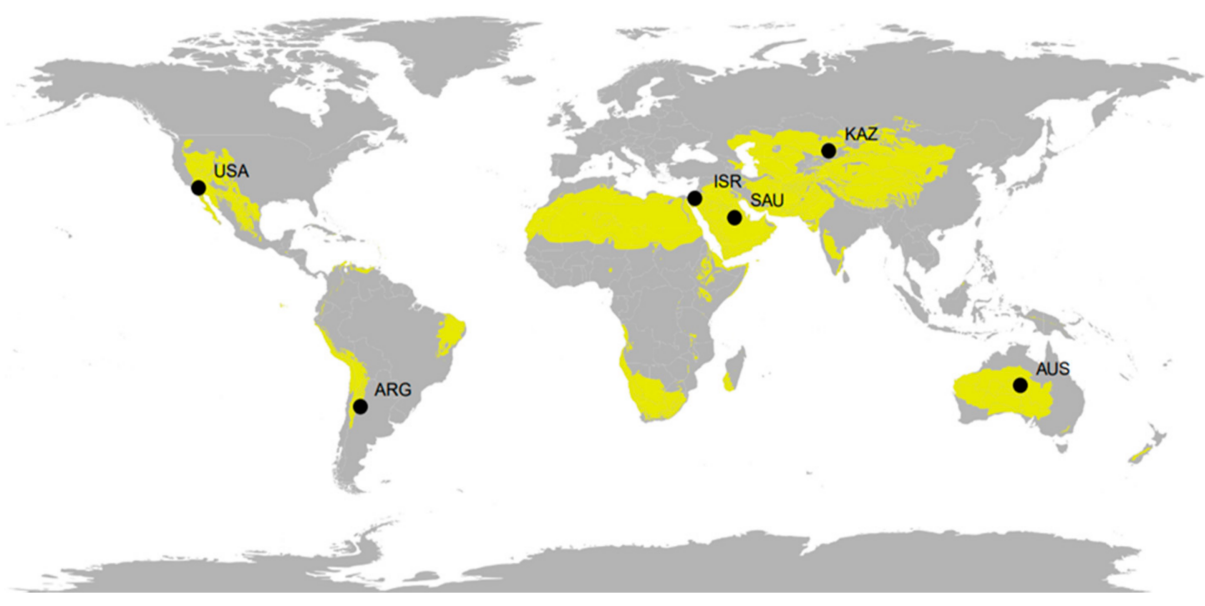

Figure 1. Sampling locations and desert and arid shrubland biomes colored yellow.

Table 1. Study site characteristics. Mean annual temperature (MAT), mean annual precipitation (MAP), soil organic carbon (C), total nitrogen (N), available phosphorus (P), Argentina (ARG), Australia (AUS), Israel (ISR), Kazakhstan (KAZ), Saudi Arabia (SAU) and United States of America (USA). Ecoregion is from [36].

\begin{tabular}{|c|c|c|c|c|c|c|c|c|c|}
\hline Site & $\begin{array}{l}\text { Country, District and } \\
\text { the Settlement Nearest } \\
\text { to the Site }\end{array}$ & Ecoregion & Coordinates & MAT $\left({ }^{\circ} \mathrm{C}\right)$ & MAP (mm) & $\mathrm{pH}$ & P (mg/100 g Soil) & $\mathbf{N}(\%)$ & C (\%) \\
\hline ARG & $\begin{array}{c}\text { Argentina, La Rioja, Los } \\
\text { Colorados }\end{array}$ & Dry chaco & $\begin{array}{l}29.58,11 \mathrm{~S} \\
67.5,29 \mathrm{~W}\end{array}$ & 19.2 & 319 & 6.40 & 11.40 & 0.03 & 0.60 \\
\hline AUS & $\begin{array}{l}\text { Australia, Northern } \\
\text { territory, Alice Springs }\end{array}$ & $\begin{array}{l}\text { Central } \\
\text { Ranges xeric } \\
\text { scrub }\end{array}$ & $\begin{array}{c}23.46,01 \mathrm{~S} \\
133.52,32 \mathrm{E}\end{array}$ & 22.4 & 278 & 4.90 & 61.00 & 0.03 & 0.29 \\
\hline ISR & $\begin{array}{l}\text { Israel, Southern district, } \\
\text { Mitzpe Ramon }\end{array}$ & $\begin{array}{l}\text { Mesopotamian } \\
\text { shrub desert }\end{array}$ & $\begin{array}{l}30.36,35 \mathrm{~N} \\
34.44,31 \mathrm{E}\end{array}$ & 17.1 & 113 & 7.47 & 0.38 & 0.09 & 0.62 \\
\hline KAZ & $\begin{array}{l}\text { Kazakhstan, Zhambyl } \\
\text { district, Taukum desert }\end{array}$ & $\begin{array}{l}\text { Central Asian } \\
\text { northern } \\
\text { desert }\end{array}$ & $\begin{array}{l}44.24,41 \mathrm{~N} \\
75.31,15 \mathrm{E}\end{array}$ & 10.6 & 192 & 7.59 & 1.98 & 0.03 & 0.42 \\
\hline SAU & $\begin{array}{l}\text { Saudi Arabia, Riyadh, } \\
\text { Arabian desert }\end{array}$ & $\begin{array}{c}\text { Arabian } \\
\text { desert }\end{array}$ & $\begin{array}{l}24.58,58 \mathrm{~N} \\
46.50,60 \mathrm{E}\end{array}$ & 25.9 & 105 & 8.50 & 22.60 & 0.10 & 0.45 \\
\hline USA & $\begin{array}{c}\text { United States of } \\
\text { America, California, } \\
\text { Boyd }\end{array}$ & $\begin{array}{c}\text { Sonoran } \\
\text { desert }\end{array}$ & $\begin{array}{c}33.39,02 \mathrm{~N} \\
116.22,30 \\
\mathrm{~W}\end{array}$ & 21.2 & 141 & 7.35 & 6.51 & 0.05 & 0.37 \\
\hline
\end{tabular}


Table 2. Life zone and common plant species in study sites. Taxonomy follows "The Plant List" (www.theplantlist.org). Abbreviation spp is used when it was possible to recognize only genus. Dominants are indicated in bold. Life zone is from [37]. The C3, C4, and CAM (Crassulacean acid metabolism) photosynthesis models are based on a common photosynthetic core with additional fluxes to capture the spatial and temporal separations of $\mathrm{CO}_{2}$ uptake and fixation.

\begin{tabular}{|c|c|c|c|c|c|}
\hline Site & Life Zone & $\begin{array}{c}\text { Vegetation } \\
\text { Coverage (\%) }\end{array}$ & Common Species & Growth Form & $\begin{array}{c}\text { Photosynthetic } \\
\text { Pathway }\end{array}$ \\
\hline \multirow{12}{*}{ ARG } & \multirow{12}{*}{$\begin{array}{l}\text { Warm temperate } \\
\text { desert scrub }\end{array}$} & \multirow{12}{*}{20} & Larrea cuneifolia & Shrub & $\mathrm{C} 3$ \\
\hline & & & Opuntia articulata & Forb & CAM \\
\hline & & & Zuccagnia punctata & Shrub & $\mathrm{C} 3$ \\
\hline & & & Atriplex lampa & Shrub & $\mathrm{C} 4$ \\
\hline & & & Bouteloua aristidoides & Grass & $\mathrm{C} 4$ \\
\hline & & & Cottea pappophoroides & Grass & $\mathrm{C} 4$ \\
\hline & & & Cyclolepis genistoides & Shrub & $\mathrm{C} 3$ \\
\hline & & & Gymnocalycium schickendantzii & Forb & $\mathrm{C} 3$ \\
\hline & & & Neobouteloua lophostachya & Grass & $\mathrm{C} 4$ \\
\hline & & & Pappophorum philippianum & Grass & $\mathrm{C} 4$ \\
\hline & & & Porophyllum obscurum & Forb & $\mathrm{C} 3$ \\
\hline & & & Prosopis chilensis & Tree & $\mathrm{C} 3$ \\
\hline \multirow{7}{*}{ AUS } & \multirow{7}{*}{$\begin{array}{l}\text { Subtropical desert } \\
\text { scrub }\end{array}$} & \multirow{7}{*}{$60-80$} & Cenchrus ciliaris & Grass & $\mathrm{C} 3$ and $\mathrm{C} 4$ \\
\hline & & & Acacia spp & Tree & $\mathrm{C} 3$ \\
\hline & & & Aristida contorta & Grass & $\mathrm{C} 3$ and $\mathrm{C} 4$ \\
\hline & & & Triraphis mollis & Grass & $\mathrm{C} 3$ and $\mathrm{C} 4$ \\
\hline & & & Eragrostis barrelieri & Grass & $\mathrm{C} 4$ \\
\hline & & & Calocephalus platycephalus & Forb & $\mathrm{C} 3$ \\
\hline & & & Wahlenbergia spp & Forb & $\mathrm{C} 3$ \\
\hline \multirow{6}{*}{ ISR } & \multirow{6}{*}{$\begin{array}{l}\text { Warm temperate } \\
\text { desert scrub }\end{array}$} & \multirow{6}{*}{10} & Asphodelus ramosus & Forb & $\mathrm{C} 3$ \\
\hline & & & Erodium crassifolium & Forb & $\mathrm{C} 3$ \\
\hline & & & Helianthemum viscarium & Forb & $\mathrm{C} 3$ \\
\hline & & & Plantago afra & Forb & C3 \\
\hline & & & Ballota undulata & Forb & $\mathrm{C} 3$ \\
\hline & & & Pterocephalus brevis & Forb & $\mathrm{C} 3$ \\
\hline \multirow{15}{*}{ KAZ } & \multirow{15}{*}{$\begin{array}{l}\text { Cool temperate } \\
\text { desert scrub }\end{array}$} & \multirow{15}{*}{20} & Hordeum spontaneum & Grass & $\mathrm{C} 3$ \\
\hline & & & Bassia prostrata & Shrub & $\mathrm{C} 3$ \\
\hline & & & Heliotropium arguzioides & Forb & C3 \\
\hline & & & Artemisia semiarida & Shrub & $\mathrm{C} 3$ \\
\hline & & & Artemisia campestris & Forb & $\mathrm{C} 3$ \\
\hline & & & Eremurus inderiensis & Forb & $\mathrm{C} 3$ \\
\hline & & & Allium tulipifolium & Forb & $\mathrm{C} 3$ \\
\hline & & & Ceratocarpus arenarius & Forb & $\mathrm{C} 3$ \\
\hline & & & Astragalus maximowiczii & Shrub & $\mathrm{C} 3$ \\
\hline & & & Ammodendron bifolium & Shrub & $\mathrm{C} 3$ \\
\hline & & & Agropyron fragile & Grass & $\mathrm{C} 3$ \\
\hline & & & Bromus tectorum & Grass & $\mathrm{C} 3$ \\
\hline & & & Buglossoides arvensis & Forb & $\mathrm{C} 3$ \\
\hline & & & Consolida camptocarpa & Forb & $\mathrm{C} 3$ \\
\hline & & & Calligonum aphyllum & Shrub & $\mathrm{C} 4$ \\
\hline \multirow{2}{*}{ SAU } & \multirow{2}{*}{ Subtropical desert } & \multirow{2}{*}{$<5$} & Stipagrostis plumosa & Grass & $\mathrm{C} 4$ \\
\hline & & & Lasiurus scindicus & Grass & $\mathrm{C} 4$ \\
\hline \multirow{7}{*}{ USA } & \multirow{7}{*}{$\begin{array}{l}\text { Warm temperate } \\
\text { desert scrub }\end{array}$} & \multirow{7}{*}{30} & Larrea tridentata & Shrub & $\mathrm{C} 3$ \\
\hline & & & Ferocactus cylindraceus & Stem succulent & $\mathrm{C} 3$ \\
\hline & & & Opuntia littoralis & Stem succulent & $\mathrm{C} 3$ \\
\hline & & & Parkinsonia florida & Tree & $\mathrm{C} 3$ \\
\hline & & & Cylindropuntia bigelovii & Stem succulent & $\mathrm{C} 3$ \\
\hline & & & Salvia apiana & Shrub & $\mathrm{C} 3$ \\
\hline & & & Condea emoryi & Shrub & $\mathrm{C} 3$ \\
\hline
\end{tabular}


The climatic variables mean annual temperature and mean annual precipitation were taken from the CHELSA database [38]. Information on the photosynthetic pathway is based on sources [39-44]. Information about the previously recorded distribution of individual AM fungal taxa was taken from the MaarjAM database, which classifies the central part of published Glomeromycota small-subunit (SSU) rRNA gene sequences into phylogenetically delimited sequence clusters-virtual taxa (VT) $[45,46]$. Virtual taxa are phylogenetically-defined Operational Taxonomic Units (OTUs) with the approximate resolution of morphologically-defined AM fungal species. For taxa identified from desert samples, this information was used to assess in which biomes they had been previously recorded.

\subsection{Soil Analyses}

We determined soil $\mathrm{pH}$, total $\mathrm{N}$ and organic $\mathrm{C}$, as well as content of plant available $\mathrm{P}$, $\mathrm{K}, \mathrm{Mg}$ and $\mathrm{Ca}$ in soils. All soil samples were air dried after sampling at room temperature and thereafter sieved using a sieve with $2 \mathrm{~mm}$ openings (Retsch, Haan, Germany). Soil $\mathrm{pH}$ was measured in 1M KCl solution following ISO 10390:2005 using the Mettler Toledo pH meter Seven Easy with electrode Mettler Toledo InLab Expert Pro. The content of total $\mathrm{N}$ in soil was determined using the Kjeldahl method [47] with the digestion block DK-20 and distillation unit UDK-126 produced by Velp Scientifica Srl (Usmate, Italy). For the determination of organic carbon content in the soil Tjurin's method was used, in which oxidation was provided by boiling soil samples in sulfuric acid $+\mathrm{K}_{2} \mathrm{Cr}_{2} \mathrm{O}_{7}$ solution [48] For determination of soil plant available P, the Mehlich III extraction method was used [49]. The content of elements in the Mehlich III extract was determined using microwave plasma atomic emission spectrometer MP-4200 (Agilent Technologies, Santa Clara, CA, USA). Chemical analyses were performed at the Institute of Agricultural and Environmental Sciences, Estonian University of Life Sciences, Tartu, Estonia.

\subsection{Molecular Methods and Bioinformatics}

DNA was extracted from $5 \mathrm{~g}$ of dried soil using a PowerMax ${ }^{\circledR}$ Soil DNA Isolation Kit (MoBio Laboratories, Carlsbad, CA, USA), with the following modifications described by [50]: (1) bead solution tubes were shaken at $60^{\circ} \mathrm{C}$ for $10 \mathrm{~min}$ at $100 \mathrm{rpm}$ in the shaking incubator, and (2) the samples were dried for $10 \mathrm{~min}$ at room temperature under a fume hood before adding the final elution buffer. We chose to use the SSU marker region since it is widely used in AM fungal community surveys [46] and a rich database of SSU-based phylogroup diversity is already available [45]. It also exhibits good amplification of most AM fungal families and suitable barcode properties compared with other available marker regions, such as the Internal Transcribed Spacer (ITS) regions [51-53]. AM fungal sequences were amplified from soil DNA extracts using AM fungal specific primers for the SSU ribosomal RNA gene: WANDA [54] and AML2 [55]. A first PCR was conducted with amplicon specific primers linked to Illumina Nextera XT sequencing adapters (Illumina forward primer adaptor: $5^{\prime}$ TCGTCGGCAGCGTCAGATGTGTATAAGAGACAG-3'; Illumina reverse primer adaptor: 5'-GTCTCGTGGGCTCGGAGATGTGTATAAGAGACAG-3'). The PCR mixture contained $5 \mu \mathrm{L}$ of 5 XHOT FirePol Blend Master Mix (Solis Biodyne, Tartu, Estonia); $0.5 \mu \mathrm{L}$ of each $20 \mu \mathrm{M}$ primer; $1 \mu \mathrm{L}$ of template DNA and nuclease-free water to reach a total reaction volume of $25 \mu \mathrm{L}$. The PCR was performed under the following cycling conditions: $95^{\circ} \mathrm{C}$ for $3 \mathrm{~min}$, 40 cycles of $95^{\circ} \mathrm{C}$ for $30 \mathrm{~s}, 55^{\circ} \mathrm{C}$ for $30 \mathrm{~s}, 72{ }^{\circ} \mathrm{C}$ for $30 \mathrm{~s}$ followed by $72{ }^{\circ} \mathrm{C}$ for $5 \mathrm{~min}$. A second PCR was performed with Nextera XT index-adapters. The reaction mix contained $15 \mu \mathrm{L}$ KAPA HiFi Hotstart PCR mix; $5 \mu \mathrm{L}$ of Nextera XT index 1 Primer (N7xxx); $5 \mu \mathrm{L}$ of Nextera XT index 2 Primer (E5xxx); $5 \mu$ l of DNA $\left(10 \mathrm{ng} \mu \mathrm{L}^{-1}\right)$ and MQ water to reach a total reaction volume of $30 \mu \mathrm{L}$. PCR was performed under following cycling conditions: $95^{\circ} \mathrm{C}$ for $3 \mathrm{~min}$, seven cycles of $95{ }^{\circ} \mathrm{C}$ for $30 \mathrm{~s}, 55^{\circ} \mathrm{C}$ for $30 \mathrm{~s}, 72{ }^{\circ} \mathrm{C}$ for $30 \mathrm{~s}$ followed by $72{ }^{\circ} \mathrm{C}$ for $5 \mathrm{~min}$. After the second PCR, samples were purified with Agencourt AMPure XP beads and pooled. The resulting mix was sequenced on the Illumina MiSeq platform, using a $2 \times 300$ bp paired-read sequencing approach, at Asper Biogene (Tartu, Estonia). 
Demultiplexed paired-end reads were analyzed following the bioinformatics steps provided by Vasar et al. [56]. Primer sequences were matched allowing 1 mismatch for both pairs and primers were removed from the paired-end sequences. After removal of barcode and primer sequences, only pairs where both reads had an average quality score of $\geq 30$ were retained. Quality filtered paired-end reads were combined into pairs using FLASh (v1.2.10, [57]) with default parameters (10-300 bp overlap with at least 75\% identity). Orphan reads (paired-end reads, where one pair had low average quality or primer mismatch) and unpaired reads (paired-end reads that did not meet the conditions to be combined) were removed from the analyses. Vsearch (v2.14.1, [58]) was used to remove putative chimeric reads using the default parameters and the Maarj $A M$ database [45] as a reference set. Retained reads were subjected to a BLAST search (v 2.10.0, [59]) against VT in the Maarj $A M$ database using $97 \%$ identity and $95 \%$ alignment length thresholds. Cultured taxa were defined as those VT that contain sequences of known morphospecies identity according to the MaarjAM database [45].

Raw reads from this targeted locus study have been deposited in the NCBI SRA (BioProject PRJNA659159), and representative sequences of each VT have been deposited in the NCBI GenBank under the accession number KELL00000000.

\subsection{Statistical Analysis}

Sampling intensity was assessed using rarefaction curves (the rarefy function from the $R$ package [60] vegan [61]). In order to account for differences in sampling intensity between sites, we used the Shannon and Simpson index-based effective numbers of species and extrapolation to an asymptote implemented in the iNEXT software [62]. The asymptotic diversity equates to expected local diversity at full sample coverage. This approach makes it possible to maximize use of the information in the original data, which would be lost with rarefying approaches where many observations are removed.

To address phylogenetic community composition, we used a phylogenetic tree constructed using neighbor-joining with $n j$ function from the ape package in $\mathrm{R}$ [63] containing the type sequences of all VT in the MaarjAM database [64]. We additionally constructed a phylogenetic tree (Figure S4) of the aligned VT type sequences of AM fungi found in the desert samples and all AM fungal VT from MaarjAM database using neighbor-joining with $n j$ function from the ape package in R. In order to represent phylogenetic community composition, we performed non-metric multidimensional scaling (NMDS) using a between-sample phylogenetic distance matrix. The distance matrix, representing mean phylogenetic distance (mpd) separating pairs of taxa in different samples, was based on AM fungal VT presence-absence and was constructed using the function comdist from the picante package [65]. Variation in AM fungal and plant community composition were visualized using principal coordinates analysis (PCoA) [66]. Sample dissimilarity was calculated using the Jaccard index based on the presence and absence of AM fungal VT or plant OTU. The environmental factors (annual mean temperature and precipitation, soil organic $\mathrm{C}$, total $\mathrm{N}$, mobile $\mathrm{P}$ and $\mathrm{pH}$ ) were fitted to the ordination with the envfit function from the vegan package in $\mathrm{R}$ and visualized on the plot of NMDS or PCoA axis scores using arrows for AM fungal and plant data respectively. We investigated whether AM fungi present in desert samples represented random phylogenetic subsets of taxa from globally, continent or biogeographic realm. The global pool contained all the MaarjAM VT sequences while the desert available pool contained only VT recorded in this study. Mean pairwise phylogenetic distance (mpd) between VT for each sample was calculated using the function ses.mpd from R package picante.

We established whether the AM fungal taxa recorded in our samples had previously been recorded in desert and xeric shrublands using information from the Maarj $A M$ database. For each VT we estimated an aridity index by calculating the fraction of its records in the Maarj $A M$ database derived from "deserts and xeric shrublands". A communitylevel aridity index was then estimated for each desert sample by calculating the mean aridity index of VT recorded in the sample. Random null models were then constructed 
for each sample by randomly selecting $\mathrm{n}$ VT, where $\mathrm{n}$ corresponds to the number of VT recorded in the empirical sample, among different pools of VT: All VT recorded in the MaarjAM database; or those VT previously recorded in the continent or biogeographic realm where the sample was collected. We repeated this procedure 999 times, each time calculating the mean aridity index for the randomly selected community. We compared the observed value and randomized values by calculating a Z-value (mean_observedmean_randomized/standard deviation_randomized) to assess whether the representation of desert and xeric shrubland-affiliated VT in empirical samples was different from random expectation. Significant deviation from the random null model was indicated by Z-values more extreme than $-1.96 / 1.96$.

\section{Results}

The AM fungal dataset contained 542,129 quality filtered paired reads. 23,447 chimeric reads were found and removed from the analyses. BLAST resulted in 241,729 reads identified as AM fungi (containing 55 VT and 1 unpublished Glomus JD-GL07). Singletons were omitted from the BLAST results leaving a total of $49 \mathrm{VT}$ and 1 unpublished (Table S2). Therefore, 21 taxa (42\%) were identified as cultured taxa. Glomeraceae was the most common family, while Claroideoglomeraceae, Diversisporaceae and Acaulosporaceae were represented with lower frequency and abundance. Sequences not getting a hit against MaarjAM database were subjected to identification with BLAST against GenBank. BLAST hits were distributed as following: 56\% Metazoa (90\% Collembola), 39\% Fungi (77\% Chytridiomycetes) and 1\% Viridiplantae. No novel VT were identified among the non-AM fungal reads.

Analysis of AM fungal diversity showed that the Israeli site was the most diverse, and the Saudi Arabian site was the least diverse, whichever diversity measure was used (Table 3). Extrapolated Shannon and Simpson diversity estimates indicated that the United States site tended to be the second most diverse and the Kazakhstan site the third most diverse. Rarefaction curves showed that samples from Israel and Australia, perhaps also from Kazakhstan, had sufficient sequencing depth as they approached an asymptote, but others exhibited insufficient sequencing depth, suggesting that the extrapolated diversity estimates are likely to better capture the true diversity of the communities (Figure 2).

Table 3. AM fungal virtual taxa (VT) diversity at study sites-ARG, AUS, ISR, KAZ, SAU and USA. Observed richness and extrapolated values of richness, Shannon and Simpson diversity are given. Extrapolation was implemented in the iNEXT software [62]. Standard error (S.E.), lower confidence limits (LCL) and upper confidence limits (UCL).

\begin{tabular}{|c|c|c|c|c|c|c|c|}
\hline & & ARG & AUS & ISR & KAZ & SAU & USA \\
\hline \multirow{5}{*}{ Species richness } & Observed & 13.0 & 17.0 & 36.0 & 13.0 & 3.0 & 4.0 \\
\hline & Estimated & 17.5 & 18.0 & 37.6 & 13.0 & 3.0 & 4.0 \\
\hline & S.E. & 7.19 & 2.3 & 2.16 & 0.74 & 0.48 & 0.0 \\
\hline & LCL & 13.5 & 17.07 & 36.22 & 13.0 & 3.0 & 4.0 \\
\hline & UCL & 53.91 & 31.25 & 47.79 & 15.16 & 4.5 & 4.0 \\
\hline \multirow{5}{*}{ Shannon diversity } & Observed & 1.92 & 1.89 & 6.6 & 2.61 & 1.34 & 3.8 \\
\hline & Estimated & 1.92 & 1.89 & 6.6 & 2.61 & 1.34 & 3.81 \\
\hline & S.E. & 0.03 & 0.01 & 0.02 & 0.02 & 0.05 & 0.03 \\
\hline & LCL & 1.92 & 1.89 & 6.6 & 2.61 & 1.34 & 3.8 \\
\hline & UCL & 1.98 & 1.91 & 6.64 & 2.66 & 1.43 & 3.87 \\
\hline \multirow{5}{*}{ Simpson diversity } & Observed & 1.46 & 1.51 & 4.52 & 1.9 & 1.18 & 3.62 \\
\hline & Estimated & 1.46 & 1.51 & 4.52 & 1.9 & 1.18 & 3.63 \\
\hline & S.E. & 0.02 & 0.01 & 0.02 & 0.02 & 0.03 & 0.06 \\
\hline & LCL & 1.46 & 1.51 & 4.52 & 1.9 & 1.18 & 3.62 \\
\hline & UCL & 1.5 & 1.52 & 4.56 & 1.94 & 1.23 & 3.74 \\
\hline
\end{tabular}




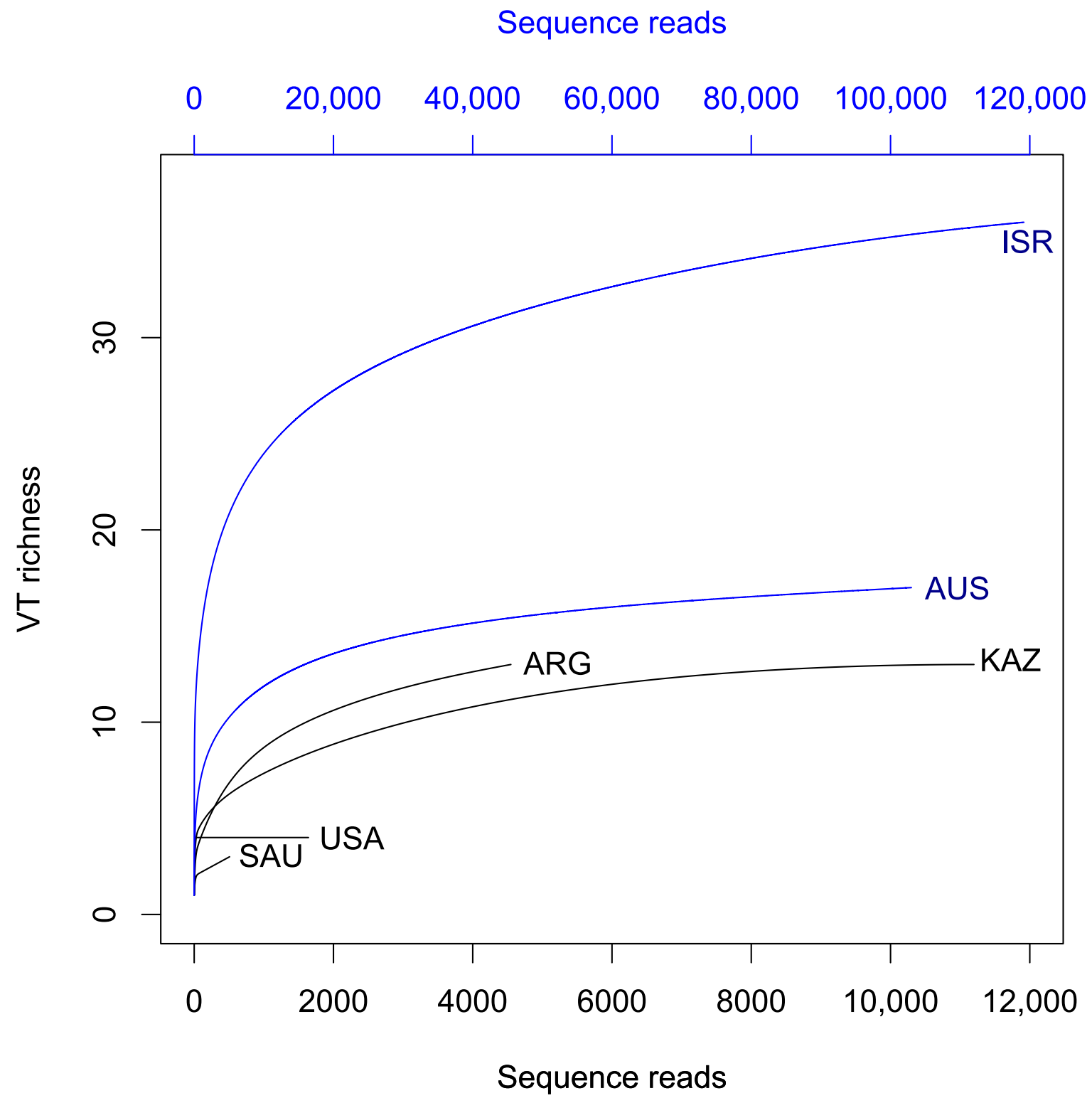

Figure 2. Rarefaction curves for study sites-accumulation of AM fungal VT in relation to the number of reads. Blue lines use scaling of axis on the top. Part of the samples AUS and ISR curves are cut-off to fit the graph.

Many of the AM fungal taxa identified in this study have previously been recorded in arid biomes, but most are also widely distributed, both geographically and ecologically, occurring in several regions and biomes globally (Figures S1 and S2). The Saudi Arabian site was different from others-all three taxa recorded in this site were representatives of Diversisporaceae and all exhibit relatively narrow ecological distribution (Figure S1). A randomization test showed that "desert affiliated" VT (i.e., VT which have been, according to Maarj $A M$ database, recorded from deserts and xeric shrublands in any part of the globe) were over-represented in the samples from Australia, Argentina, Israel and Kazakhstan, compared to records in the database originating either from the same continent or biogeographic realm (Table 4). 
Table 4. Results of randomization tests. Values in the table are $Z$ values, where $Z>1.96$ (bold) indicates significant positive deviation in the community aridity index compared with a random null model. The random null model consisted of sampling VT present globally, or present in the continent or biogeographic realm corresponding to the sample location.

\begin{tabular}{ccccccc}
\hline Scale & ARG & AUS & ISR & KAZ & SAU & USA \\
\hline All VT & 1.560 & 1.337 & 1.612 & 1.551 & -0.406 & -0.331 \\
Continent VT & $\mathbf{3 . 2 1 7}$ & $\mathbf{3 . 0 8 8}$ & $\mathbf{2 . 9 7 0}$ & $\mathbf{2 . 4 2 7}$ & -0.554 & -0.166 \\
Realm VT & $\mathbf{3 . 2 5 1}$ & $\mathbf{3 . 1 8 0}$ & 1.254 & 1.417 & -0.447 & -0.152 \\
\hline
\end{tabular}

The phylogenetic composition of AM fungal communities (Figure 3) in samples formed three groups on the ordination biplot. The first group comprised samples from Australia, Argentina and Israel, which also exhibited the highest observed AM fungal taxon richness; the second group comprised samples from the USA and Kazakhstan, which both exhibited relatively high extrapolated fungal diversity and the third group consisted of a single sample from Saudi Arabia, which was extremely taxon poor. For comparison presence-absence based AM fungal VT ordination biplot (Figure S3) was also generated showing similar ordination as the AM fungal phylogenetic composition. AM fungi found in the three desert samples (AUS, ARG and KAZ) were phylogenetically more closely related than would be expected from random sampling of taxa from the global VT phylogeny (containing VT type sequences from the MaarjAM database, Table S1).

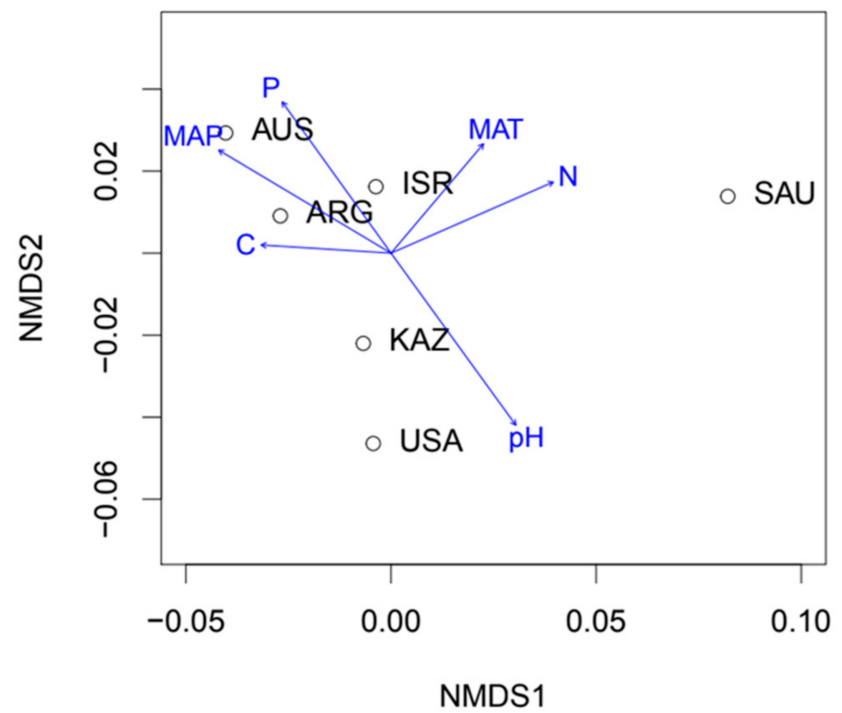

Figure 3. NMDS ordination showing variation in AM fungal phylogenetic community composition for desert samples. The ordination was calculated using mean pairwise phylogenetic distance between VT in samples. Arrows show significant correlations of climatic and soil-chemical parameters with the NMDS configuration.

\section{Discussion}

This study provides a first insight into AM fungal communities occurring in desert ecosystems across the globe. In general, the study site in Israel was the most taxon rich, while sites in Argentina, Australia, Kazakhstan and United States exhibited lower richness and diversity. Only three AM fungal taxa, all from the family Diversisporaceae, were recorded in a Saudi Arabian site. This site was also characterized by the highest mean annual temperature and the lowest annual precipitation rate. Most of the AM fungal taxa found in desert soils are predominantly widespread and occur in a wide range of biome types globally. Virtual taxa that have been previously recorded in deserts or xeric shrublands were over-represented in four of the six studied sites. VT identified from the samples were 
phylogenetically clustered compared with global taxon pool, suggesting that nonrandom assembly processes, notably habitat filtering, may have shaped fungal assemblages.

Our hypothesis that the diversity of AM fungi in desert ecosystems is low was only partially confirmed. The number of AM fungal taxa recorded was very low under the harshest conditions of high temperature and low precipitation. The total number of VT recorded in other desert sites was still below the average of around 50 VT per site among Maarj $A M$ database records [67]. Our result is broadly consistent with previous spore-based studies showing variation in AM fungal diversity between different habitat types within desert landscapes and the recording of more taxa in benign sites [25-27]. At the Israeli site, AM fungal diversity was unexpectedly high despite the abiotic conditions being fairly similar to those at other sites. This may be related to the enhanced local dispersal of AM fungi due to grazing or some other past human impact, but further study would be needed to understand diversity patterns in the region. At the same time sequencing depth at some of the sites was insufficient to describe AM fungal richness, meaning that comparisons of richness with previous studies should be made with caution.

The phylogenetic and taxonomic composition of AM fungal communities was primarily driven by soil $\mathrm{pH}$. This finding supports emerging evidence that $\mathrm{pH}$ plays a central role in the assembly of multiple soil communities [68]. Likely mechanisms underlying $\mathrm{pH}$ effects on microbial communities include mediation of nutrient availability. $\mathrm{pH}$ has a major impact of the mobility of multiple compounds, and hence on many connected biological processes in soil $[69,70]$. The impact of climatic factors, which have been considered the main global drivers of fungal community composition [71], appeared to cause the contrast between the Saudi Arabian site and other sites. The effect of soil factors on AM fungal communities is in line with previous work $[10,71]$.

Although information about the mycorrhizal growth response of plant species is accumulating [72], there is no information about the responses of those species that were common in our study sites. Two sites-Argentina and Australia-were notable due to the relatively high proportion of grasses in the vegetation. The plant species also differed in terms of their photosynthetic pathways. In general, $\mathrm{C} 4$ grasses tend to respond more positively to mycorrhizal inoculation than C3 grasses [73]. However, Worschel et al. [18] found the opposite pattern under drought conditions, and suggested that the greatest benefit of AM fungi for $\mathrm{C} 4$ grasses may be increased nutrient acquisition, while for C3 grasses it may be water acquisition. Indeed, the two sites with the highest mean annual precipitation (MAP), Argentina and Australia, comprised more $\mathrm{C} 4$ species among common plants, while $\mathrm{C} 3$ species dominated in drier sites. However, whether this difference could be related to mycorrhiza in any way would need further investigation. The Saudi Arabian site was again exceptional, in that the only recorded grass was a C4 species. Previous work has recorded several unique AM fungal taxa in desert ecosystems [25], and we hypothesized that certain AM fungal taxa are characteristic of desert ecosystems and are rare in other biomes. This was not strongly supported by data. Desert AM fungal community composition varied according to abiotic conditions, but the fungal taxa recorded were mostly widespread. However, many of the recorded taxa had previously been recorded in dry habitats according to the Maarj $A M$ database, and an abundant taxon in three of our study sites-VT388 (Glomus sp.) - was a dominant taxon in a xeric shrubland in Spain [74]. Moreover, based on an analysis of MaarjAM database records, the fungal taxa recorded at four of the six sites in this study exhibited a greater affiliation for desert and xeric shrubland ecosystems than might be expected from a random selection of VT. AM fungal VT identified from the desert samples also exhibited phylogenetic clustering, which may suggest that habitat filtering shaped the fungal assemblages [75]. In the Saudi Arabian site only three Diversispora taxa with narrow geographic and ecological distributions were recorded. Former studies have reported the presence of Diversispora taxa in the Arabian desert [20], but also in the early stages of primary succession [76,77] and in disturbed ecosystems in human impacted landscapes $[78,79]$. The Saudi Arabian site has a very sparse plant community, and might, to some extent, resemble an early successional ecosystem. It 
is also located in the central part of a large desert region, so certain fungal taxa may have not reached the study site due to dispersal limitation. Diversispora generally have small spores, which might also allow relatively efficient aerial dispersal [24]. Further studies are required to investigate the affiliation of Diversispora taxa with desert habitats.

AM fungal taxa exhibit differences in their ability to produce spores that facilitate long distance dispersal [80]. Only AM fungal taxa that produce spores can be multiplied with the current methods used to bring AM fungi to culture. Cultured AM fungal taxa are thus expected to be better colonizers than uncultured taxa [80]. Among the VT recorded in desert sites, $42 \%$ represented cultured taxa. This percentage is higher that common in natural habitats and correspond to what has been recorded in disturbed unwooded sites [81]. One of the reasons for this may be the better ability of cultured taxa to spread, which allows to inhabit areas with sparse vegetation and partly also unstable substrates.

The current study provides a first insight into desert soil AM fungal communities, based on environmental DNA metabarcoding. Our results show that desert AM fungal community composition and diversity vary according to the ecological conditions. Low diversity and in some cases also specific AM fungal community composition are likely to be related to harsh abiotic conditions and perhaps also to dispersal limitation in large desert areas. As climate change is likely to lead to desertification in many regions, more data on AM fungi as important mutualists should be collected to understand and predict ecosystem change. If AM fungal taxa well suited to desert conditions are identified, their use as inoculum could also be considered, for example in ecosystem restoration. Cultured taxa of AM fungi, which are common in deserts, may be the first candidates for use as an inoculum in the restoration of degraded arid ecosystems.

Supplementary Materials: The following are available online at https:/ /www.mdpi.com/2076-2 607/9/2/229/s1, Figure S1: Biome occurrence worldwide of AM fungal virtual taxa (VT) recorded in this study, Figure S2: Biome occurrence worldwide of AM fungal virtual taxa (VT) recorded in this study, Figure S3: Two-dimensional principal coordinate analysis (PCoA) ordination plots, indicating variation in the composition of desert AM fungal communities, Figure S4: Neighborjoining phylogenetic tree of full MaarjAM VT type sequences based on Jukes Cantor distance, Table S1: Mean pairwise phylogenetic distances (mpd) between virtual taxa (VT) in different desert samples, Table S2: AM fungal community data matrix with environmental variables. (Table S2.xlsx).

Author Contributions: Conceptualization, M.Z. and W.N.H.; methodology, J.D., J.O., Y.M., S.-K.S., M.V.; software, M.V. and Y.M.; formal analysis, M.V., S.-K.S., J.D.; investigation, M.M., M.Ö., M.Z.; resources, S.A.-Q., M.Z.; data curation, K.K., A.A.A., V.G.O., J.J.C., S.I.G., S.A.-Q.; writing-original draft preparation, M.V., M.Z., M.M.; writing—review and editing, J.D., M.Ö., S.I.G., W.N.H., V.G.O., J.J.C.; visualization, Y.M., S.-K.S., M.V.; project administration, M.Z., S.A.-Q. All authors have read and agreed to the published version of the manuscript.

Funding: This study was supported by grants from the European Regional Development Fund (Centre of Excellence EcolChange) and by the University of Tartu PLTOM20903. Estonian Research Council grants PRG1065 and MOBTP105. VO and AA thank Russian Science Foundation (\#19-1400038) for financial support. We are grateful to Philip L. Boyd Deep Canyon Desert Research Center (Deep Canyon), part of the University of California Natural Reserve System, doi:10.21973/N3V66D for allowing us to sample.

Institutional Review Board Statement: Not applicable.

Informed Consent Statement: Not applicable.

Data Availability Statement: Data is contained within the article or Supplementary Material.

Conflicts of Interest: The authors declare no conflict of interest. 


\section{References}

1. Maestre, F.T.; Delgado-Baquerizo, M.; Jeffries, T.C.; Eldridge, D.J.; Ochoa, V.; Gozalo, B.; Quero, J.L.; Garcia-Gomez, M.; Gallardo, A.; Ulrich, W.; et al. Increasing aridity reduces soil microbial diversity and abundance in global drylands. Proc. Natl. Acad. Sci. USA. 2015, 112, 15684-15689. [PubMed]

2. Feng, S.; Fu, Q. Expansion of global drylands under a warming climate. Atmos. Chem. Phys. Discuss. 2013, 13, 10081-10094. [CrossRef]

3. Berdugo, M.; Delgado-Baquerizo, M.; Soliveres, S.; Hernández-Clemente, R.; Zhao, Y.; Gaitán, J.J.; Gross, N.; Saiz, H.; Maire, V.; Lehman, A.; et al. Global ecosystem thresholds driven by aridity. Science 2020, 367, 787-790. [PubMed]

4. Huang, J.; Yu, H.; Guan, X.; Wang, G.; Guo, R. Accelerated dryland expansion under climate change. Nat. Clim. Chang. 2016, 6, 166-171. [CrossRef]

5. Porembski, S.; Barthlott, W. Granitic and gneissic outcrops (inselbergs) as centers of diversity for desiccation-tolerant vascular plants. Plant Ecol. 2000, 151, 19-28.

6. Bechtold, U. Plant Life in Extreme Environments: How Do You Improve Drought Tolerance? Front. Plant Sci. 2018, 9, 543. [CrossRef]

7. Tedersoo, L.; Bahram, M.; Zobel, M. How mycorrhizal associations drive plant population and community biology. Science 2020, 367, eaba1223. [CrossRef]

8. Tedersoo, L.; Sánchez-Ramírez, S.; Kõljalg, U.; Bahram, M.; Döring, M.; Schigel, D.; May, T.; Ryberg, M.; Abarenkov, K. High-level classification of the Fungi and a tool for evolutionary ecological analyses. Fungal Divers. 2018, 90, 135-159. [CrossRef]

9. Smith, S.E.; Read, D.J. Mycorrhizal Symbiosis, 3rd ed.; Academic Press: Cambridge, UK, 2008.

10. Davison, J.; Moora, M.; Öpik, M.; Adholeya, A.; Ainsaar, L.; Bâ, A.; Burla, S.; Diedhiou, A.G.; Hiiesalu, I.; Jairus, T.; et al. Global assessment of arbuscular mycorrhizal fungus diversity reveals very low endemism. Science 2015, 349, $970-973$.

11. Al-Whaibi, M.H. Desert Plants and Mycorrhizae (A mini-review). J. Pure Appl. Microbiol. 2009, 3, 457-466.

12. Apple, M. Aspects of Mycorrhizae in Desert Plants. In Desert Plants; Springer Nature: Berlin, Germany, 2009 ; pp. 121-134.

13. Weber, S.E.; Diez, J.M.; Andrews, L.V.; Goulden, M.L.; Aronson, E.L.; Allen, M.F. Responses of arbuscular mycorrhizal fungi to multiple coinciding global change drivers. Fungal Ecol. 2019, 40, 62-71. [CrossRef]

14. Augé, R.M. Water relations, drought and vesicular-arbuscular mycorrhizal symbiosis. Mycorrhiza 2001, 11, 3-42. [CrossRef]

15. Al-Karaki, G.N.; Al-Raddad, A. Effects of arbuscular mycorrhizal fungi and drought stress on growth and nutrient uptake of two wheat genotypes differing in drought resistance. Mycorrhiza 1997, 7, 83-88. [CrossRef]

16. Brundrett, M.C. Mycorrhizal associations and other means of nutrition of vascular plants: Understanding the global diver-sity of host plants by resolving conflicting information and developing reliable means of diagnosis. Plant Soil 2009, 320, 37-77. [CrossRef]

17. Brundrett, M.C. Global diversity and importance of mycorrhizal and nonmycorrhizal plants. In Biogeography of Mycorrhizal Symbiosis; Springer: Cham, Switzerland, 2017; pp. 533-556.

18. Worchel, E.R.; Giauque, H.E.; Kivlin, S.N. Fungal symbionts alter plant drought response. Microb. Ecol. 2013, 65, 671-678. [CrossRef]

19. Propster, J.R.; Johnson, N.C. Uncoupling the effects of phosphorus and precipitation on arbuscular mycorrhizas in the Serengeti. Plant Soil 2015, 388, 21-34. [CrossRef]

20. Symanczik, S.; Courty, P.-E.; Boller, T.; Wiemken, A.; Al-Yahya'ei, M.N. Impact of water regimes on an experimental com-munity of four desert arbuscular mycorrhizal fungal (AMF) species, as affected by the introduction of a non-native AMF species. Mycorrhiza 2015, 25, 639-647. [CrossRef]

21. Klironomos, J.N.; Hart, M.M.; Gurney, J.E.; Moutoglis, P. Interspecific differences in the tolerance of arbuscular mycorrhizal fungi to freezing and drying. Can. J. Botany 2001, 79, 1161-1166.

22. Deveautour, C.; Power, S.A.; Barnett, K.L.; Ochoa-Hueso, R.; Donn, S.; Bennett, A.E.; Powell, J.R. Temporal dynamics of mycorrhizal fungal communities and co-associations with grassland plant communities following experimental manipulation of rainfall. J. Ecol. 2020, 108, 515-527. [CrossRef]

23. Alpert, P. Constraints of tolerance: Why are desiccation-tolerant organisms so small or rare? J. Exp. Biol. 2006, 209 , 1575-1584. [CrossRef]

24. Aguilar-Trigueros, C.A.; Hempel, S.; Powell, J.R.; Cornwell, W.K.; Rillig, M.C. Bridging reproductive and microbial ecology: A case study in arbuscular mycorrhizal fungi. ISME J. 2019, 13, 873-884. [CrossRef] [PubMed]

25. Al-Yahya'ei, M.N.; Oehl, F.; Vallino, M.; Lumini, E.; Redecker, D.; Wiemken, A.; Bonfante, P. Unique arbuscular mycorrhizal fungal communities uncovered in date palm plantations and surrounding desert habitats of Southern Arabia. Mycorrhiza 2011, 21, 195-209. [CrossRef] [PubMed]

26. Wang, K.; He, X.; Xie, L.; Zhao, L. Arbuscular mycorrhizal fungal community structure and diversity are affected by host plant species and soil depth in the Mu Us Desert, northwest China. Arid. Land Res. Manag. 2018, 32, 198-211. [CrossRef]

27. Suleiman, M.K.; Dixon, K.; Commander, L.; Nevill, P.; Quoreshi, A.M.; Bhat, N.R.; Manuvel, A.J.; Sivadasan, M.T. Assessment of the diversity of fungal community composition associated with Vachellia pachyceras and its rhizosphere soil from Kuwait desert. Front. Microbiol. 2019, 10, 63. [CrossRef] [PubMed]

28. Talbot, J.M.; Bruns, T.D.; Taylor, J.W.; Smith, D.P.; Branco, S.; Glassman, S.I.; Erlandson, S.; Vilgalys, R.; Liao, H.-L.; Smith, M.E.; et al. Endemism and functional convergence across the North American soil mycobiome. Proc. Natl. Acad. Sci. USA 2014, 111, 6341-6346. [CrossRef] 
29. Glassman, S.I.; Peay, K.G.; Talbot, J.M.; Smith, D.P.; Chung, J.A.; Taylor, J.W.; Vilgalys, R.; BRUNS, T.D. A continental view of pine-associated ectomycorrhizal fungal spore banks: A quiescent functional guild with a strong biogeographic pattern. New Phytol. 2015, 205, 1619-1631. [CrossRef]

30. Davison, J.; Moora, M.; Jairus, T.; Vasar, M.; Öpik, M.; Zobel, M. Hierarchical assembly rules in arbuscular mycorrhizal (AM) fungal communities. Soil Biol. Biochem. 2016, 97, 63-70. [CrossRef]

31. Kivlin, S.N.; Winston, G.C.; Goulden, M.L.; Treseder, K.K. Environmental filtering affects soil fungal community composition more than dispersal limitation at regional scales. Fungal Ecol. 2014, 12, 14-25. [CrossRef]

32. Egan, C.; Li, D.-W.; Klironomos, J. Detection of arbuscular mycorrhizal fungal spores in the air across different biomes and ecoregions. Fungal Ecol. 2014, 12, 26-31. [CrossRef]

33. Vernes, K.; Dunn, L. Mammal mycophagy and fungal spore dispersal across a steep environmental gradient in eastern Aus-tralia. Austral Ecol. 2009, 34, 69-76. [CrossRef]

34. Correia, M.; Heleno, R.; da Silva, L.P.; Costa, J.M.; Rodríguez-Echeverría, S. First evidence for the joint dispersal of mycorrhizal fungi and plant diaspores by birds. New Phytol. 2019, 222, 1054-1060. [CrossRef] [PubMed]

35. Paz, C.; Öpik, M.; Bulascoschi, L.; Bueno, C.G.; Galetti, M. Dispersal of Arbuscular Mycorrhizal Fungi: Evidence and Insights for Ecological Studies. Microb. Ecol. 2020, 1-10. [CrossRef]

36. Olson, D.M.; Dinerstein, E.; Wikramanayake, E.D.; Burgess, N.D.; Powell, G.V.N.; Underwood, E.C.; D'amico, J.A.; Itoua, I.; Strand, H.E.; Morrison, J.C.; et al. Terrestrial Ecoregions of the World: A New Map of Life on Earth. BioScience 2001, 51, 933. [CrossRef]

37. Holdridge, L.R. Life Zone Ecology; Tropical Science Center: San Jose, Costa Rica, 1967.

38. Karger, D.N.; Conrad, O.; Böhner, J.; Kawohl, T.; Kreft, H.; Soria-Auza, R.W.; Zimmermann, N.E.; Linder, H.P.; Kessler, M. Climatologies at high resolution for the earth's land surface areas. Sci. Data 2017, 4, 170122. [CrossRef] [PubMed]

39. Osborne, C.P.; Salomaa, A.; Kluyver, T.A.; Visser, V.; Kellogg, E.A.; Morrone, O.; Vorontsova, M.S.; Clayton, W.D.; Simpson, D.A. A global database of C4photosynthesis in grasses. New Phytol. 2014, 204, 441-446. [CrossRef]

40. EOL Encyclopedia of Life. Available online: http:/ / eol.org (accessed on 13 January 2021).

41. Kapralov, M.V.; Smith, J.A.C.; Filatov, D.A. Rubisco evolution in C4 eudicots: An analysis of Amaranthaceae sensu lato. PLoS ONE 2012, 7, e52974. [CrossRef]

42. Blood, D.; Mitchell, A.; Bradley, J.; Addison, J. Field Guide to Common Grasses of the Southern Rangelands; Rangelands NRM: Perth, Australia, 2015.

43. Kocacinar, F.; Sage, R.F. Photosynthetic pathway alters hydraulic structure and function in woody plants. Oecologia 2004, 139, 214-223. [CrossRef]

44. Rudov, A.; Mashkour, M.; Djamali, M.; Akhani, H. A review of C4 plants in southwest Asia: An ecological, geographical and taxonomical analysis of a region with high diversity of C4 eudicots. Front. Plant Sci. 2020, 11, 546518. [CrossRef]

45. Öpik, M.; Vanatoa, A.; Vanatoa, E.; Moora, M.; Davison, J.; Kalwij, J.M.; Reier, Ü.; Zobel, M. The online database MaarjAM reveals global and ecosystemic distribution patterns in arbuscular mycorrhizal fungi (Glomeromycota). New Phytol. 2010, 188, $223-241$. [CrossRef]

46. Öpik, M.; Davison, J.; Moora, M.; Zobel, M. DNA-based detection and identification of Glomeromycota: The virtual taxonomy of environmental sequences. Botany 2014, 92, 135-147. [CrossRef]

47. van Reeuwijk, L.P. Procedures for Soil Analysis; Technical Paper 9; International Soil Reference and Information Centre: Wa-geningen, The Netherlands, 1995.

48. Vorobyova, L.A. Chemical Analysis of Soils; Moscow University Press: Moscow, Russia, 1998.

49. Soil and Plant Analysis Council. Handbook on Reference Methods for Soil Analysis; CRC: London, UK, 1992.

50. Gazol, A.; Zobel, M.; Cantero, J.J.; Davison, J.; Esler, K.J.; Jairus, T.; Öpik, M.; Vasar, M.; Moora, M. Impact of alien pines on local arbuscular mycorrhizal fungal communities-evidence from two continents. FEMS Microbiol. Ecol. 2016, 92, 073. [CrossRef] [PubMed]

51. Thiéry, O.; Vasar, M.; Jairus, T.; Davison, J.; Roux, C.; Kivistik, P.A.; Metspalu, A.; Milani, L.; Saks, Ü.; Moora, M.; et al. Sequence variation in nuclear ribosomal small subunit, internal transcribed spacer and large subunit regions of Rhizophagus irregularis and Gigaspora margarita is high and isolate-dependent. Mol. Ecol. 2016, 25, 2816-2832. [CrossRef] [PubMed]

52. Lekberg, Y.; Vasar, M.; Bullington, L.; Sepp, S.; Antunes, P.M.; Bunn, R.A.; Larkin, B.G.; Öpik, M. More bang for the buck? Can arbuscular mycorrhizal fungal communities be characterized adequately alongside other fungi using general fungal primers? New Phytol. 2018, 220, 971-976. [CrossRef]

53. Tedersoo, L.; Tooming-Klunderud, A.; Anslan, S. PacBio metabarcoding of Fungi and other eukaryotes: Errors, biases and perspectives. New Phytol. 2018, 217, 1370-1385. [CrossRef] [PubMed]

54. Dumbrell, A.J.; Ashton, P.D.; Aziz, N.; Feng, G.; Nelson, M.; Dytham, C.; Fitter, A.H.; Helgason, T. Distinct seasonal assemblages of arbuscular mycorrhizal fungi revealed by massively parallel pyrosequencing. New Phytol. 2011, 190, 794-804. [CrossRef] [PubMed]

55. Lee, J.; Lee, S.; Young, J.P.W. Improved PCR primers for the detection and identification of arbuscular mycorrhizal fungi. FEMS Microbiol. Ecol. 2008, 65, 339-349. [CrossRef] [PubMed]

56. Vasar, M.; Andreson, R.; Davison, J.; Jairus, T.; Moora, M.; Remm, M.; Young, J.P.W.; Zobel, M.; Öpik, M. Increased sequencing depth does not increase captured diversity of arbuscular mycorrhizal fungi. Mycorrhiza 2017, 27, 761-773. [CrossRef] [PubMed] 
57. Magoč, T.; Magoč, M.; Salzberg, S.L. FLASH: Fast length adjustment of short reads to improve genome assemblies. Bioinform. 2011, 27, 2957-2963. [CrossRef] [PubMed]

58. Rognes, T.; Flouri, T.; Nichols, B.; Quince, C.; Mahé, F. VSEARCH: A versatile open source tool for metagenomics. PeerJ 2016, 4, e2584. [CrossRef] [PubMed]

59. Camacho, C.; Coulouris, G.; Avagyan, V.; Ma, N.; Papadopoulos, J.; Bealer, K.; Madden, T.L. BLAST+: Architecture and ap-plications. BMC Bioinform. 2009, 10, 421. [CrossRef]

60. R Core Team. R: A Language and Environment for Statistical Computing; R Foundation for Statistical Computing: Vienna, Austria, 2019.

61. Oksanen, J.; Blanchet, F.G.; Friendly, M.; Kindt, R.; Legendre, P.; McGlinn, D.; Minchin, P.R.; OHara, R.B.; Simpson, G.L.; Solymos, P.; et al. Vegan: Community Ecology Package, R package version 2.5-6; R Foundation for Statistical Computing: Vienna, Austria, 2019.

62. Hsieh, T.C.; Ma, K.H.; Chao, A. iNEXT: An R package for rarefaction and extrapolation of species diversity (H ill numbers). Methods Ecol. Evol. 2016, 7, 1451-1456. [CrossRef]

63. Paradis, E.; Schliep, K. ape 5.0: An environment for modern phylogenetics and evolutionary analyses in R. Bioinform. 2018, 35, 526-528. [CrossRef] [PubMed]

64. Öpik, M.; Zobel, M.; Cantero, J.J.; Davison, J.; Facelli, J.M.; Hiiesalu, I.; Jairus, T.; Kalwij, J.M.; Koorem, K.; Leal, M.E.; et al. Global sampling of plant roots expands the described molecular diversity of arbuscular mycorrhizal fungi. Mycorrhiza 2013, 23, 411-430. [CrossRef] [PubMed]

65. Kembel, S.W.; Cowan, P.D.; Helmus, M.R.; Cornwell, W.K.; Morlon, H.; Ackerly, D.D.; Blomberg, S.P.; Webb, C.O. Pi-cante: R tools for integrating phylogenies and ecology. Bioinformatics 2010, 26, 1463-1464. [CrossRef]

66. Legendre, P.; Anderson, M.J. Distance-based redundancy analysis: Testing multispecies responses in multifactorial ecological experiments. Ecol. Monogr. 1999, 69, 1-24. [CrossRef]

67. Pärtel, M.; Öpik, M.; Moora, M.; Tedersoo, L.; Szava-Kovats, R.; Rosendahl, S.; Rillig, M.C.; Lekberg, Y.; Kreft, H.; Helgason, T.; et al. Historical biome distribution and recent human disturbance shape the diversity of arbuscular mycorrhizal fungi. New Phytol. 2017, 216, 227-238. [CrossRef]

68. Glassman, S.I.; Wang, I.J.; Bruns, T.D. Environmental filtering by $\mathrm{pH}$ and soil nutrients drives community assembly in fungi at fine spatial scales. Mol. Ecol. 2017, 26, 6960-6973. [CrossRef]

69. Tyler, G.; Olsson, T. Plant uptake of major and minor mineral elements as influenced by soil acidity and liming. Plant Soil 2001, 230, 307-321. [CrossRef]

70. Neina, D. The Role of Soil pH in Plant Nutrition and Soil Remediation. Appl. Environ. Soil Sci. 2019, 2019, 1-9. [CrossRef]

71. Tedersoo, L.; Bahram, M.; Põlme, S.; Kõljalg, U.; Yorou, N.S.; Wijesundera, R.L.C.; Ruiz, L.V.; Vasco-Palacios, A.M.; Thu, P.Q.; Suija, A.; et al. Global diversity and geography of soil fungi. Science 2014, 346, 1256688. [CrossRef]

72. Chaudhary, V.B.; Rúa, M.A.; Antoninka, A.; Bever, J.D.; Cannon, J.; Craig, A.; Duchicela, J.; Frame, A.; Gardes, M.; Gehring, C.; et al. MycoDB, a global database of plant response to mycorrhizal fungi. Sci. Data 2016, 3, 160028. [CrossRef] [PubMed]

73. Hoeksema, J.D.; Chaudhary, V.B.; Gehring, C.A.; Johnson, N.C.; Karst, J.; Koide, R.T.; Pringle, A.; Zabinski, C.; Bever, J.D.; Moore, J.C.; et al. A meta-analysis of context-dependency in plant response to inoculation with mycorrhizal fungi. Ecol. Lett. 2010, 13, 394-407. [CrossRef] [PubMed]

74. Alguacil, M.D.M.; Roldán, A.; Torres, M.P. Assessing the diversity of AM fungi in arid gypsophilous plant communities. Environ. Microbiol. 2009, 11, 2649-2659. [CrossRef] [PubMed]

75. Saks, Ü.; Davison, J.; Öpik, M.; Vasar, M.; Moora, M.; Zobel, M. Root-colonizing and soil-borne communities of arbuscular mycorrhizal fungi in a temperate forest understorey. Bot 2014, 92, 277-285. [CrossRef]

76. Sikes, B.; Maherali, H.; Klironomos, J.N. Arbuscular mycorrhizal fungal communities change among three stages of primary sand dune succession but do not alter plant growth. Oikos 2012, 121, 1791-1800. [CrossRef]

77. Martínez-García, L.B.; Richardson, S.J.; Tylianakis, J.M.; Peltzer, D.A.; Dickie, I.A. Host identity is a dominant driver of mycorrhizal fungal community composition during ecosystem development. New Phytol. 2014, 205, 1565-1576. [CrossRef]

78. Moora, M.; Davison, J.; Öpik, M.; Metsis, M.; Saks, Ü.; Jairus, T.; Vasar, M.; Zobel, M. Anthropogenic land use shapes the composition and phylogenetic structure of soil arbuscular mycorrhizal fungal communities. FEMS Microbiol. Ecol. 2014, 90, 609-621. [CrossRef]

79. Liu, Y.; Johnson, N.C.; Mao, L.; Shi, G.; Jiang, S.; Ma, X.; Du, G.; An, L.; Feng, H. Phylogenetic structure of arbuscular my-corrhizal community shifts in response to increasing soil fertility. Soil Biol. Biochem. 2015, 89, 196-205. [CrossRef]

80. Chagnon, P.-L.; Bradley, R.L.; Maherali, H.; Klironomos, J.N. A trait-based framework to understand life history of mycorrhizal fungi. Trends Plant Sci. 2013, 18, 484-491. [CrossRef]

81. García de León, D.; Davison, J.; Moora, M.; Öpik, M.; Feng, H.; Hiiesalu, I.; Jairus, T.; Koorem, K.; Liu, Y.; Phosri, C.; et al. Anthropogenic disturbance equalizes diversity levels in arbuscular mycorrhizal fungal communities. Glob. Chang. Biol. 2018, 24, 2649-2659. [CrossRef] 